\title{
POST-MORTEM AND SYMBIOTIC SABELLID AND SERPULID-CORAL ASSOCIATIONS FROM THE LOWER CRETACEOUS OF ARGENTINA
}

\author{
RICARDO M. GARBEROGLIO \& DARÍO G. LAZO \\ Instituto de Estudios Andinos "Don Pablo Groeber", Departamento de Ciencias Geológicas, Facultad de Ciencias Exactas y \\ Naturales, Universidad de Buenos Aires, CONICET, Pabellón II, Ciudad Universitaria, 1428, Buenos Aires, Argentina. \\ r_garberoglio@hotmail.com
}

\begin{abstract}
One morphotype of sabellids (Sabellida, Sabellidae) and two of serpulids (Sabellida, Serpulidae), found as encrusters on scleractinian ramose corals of the species Stereocaenia triboleti (Koby) and Columastrea antiqua Gerth, from the Agrio Formation (early Hauterivian) from Neuquén Basin, Argentina, are described. The identified morphotypes, Glomerula lombricus (Defrance), Mucroserpula mucroserpula Regenhardt and Propomatoceros sulcicarinatus Ware, have been previously recorded from the Early Cretaceous of the northern Tethys. Two different type of sabellid and serpulidcoral associations have been recognized. The first and more abundant association corresponds to post-mortem encrustation on corals branches. The second one corresponds to a symbiotic association between the serpulid P. sulcicarinatus and both species of corals. The serpulid tubes are recorded parallel to the coral branches reaching the upper tip of them and they were bioimmured within the coral as they grew upwards. The studied symbiotic relationship between serpulids and corals may be regarded as a mutualism as both members probably benefited each other. This type of association has similarities with recent cases of symbiosis between serpulids and corals, but had no fossil record until now.
\end{abstract}

Key words: Serpulidae, Sabellidae, Scleractinia, symbiosis, Hauterivian, Argentina.

RESUMO - São descritos um morfotipo de sabelídeo (Sabellida, Sabellidae) e dois de serpulídeos (Sabellida, Serpulidae), encontrados como epibiontes em corais escleractíneos coloniais ramificados das espécies Stereocaenia triboleti (Koby) e Columastrea antiqua Gerth, Formação Agrio, Hauteriviano inferior da bacia de Neuquén, Argentina. Os morfotipos identificados, Glomerula lombricus (Defrance), Mucroserpula mucroserpula Regenhardt e Propomatoceros sulcicarinatus Ware, têm registros na região abrangida pelo Tétis norte no Cretáceo Inferior. Dois diferentes tipos de associações de sabelídeo e de coral serpulídeo foram reconhecidos. A primeira associação e mais abundante corresponde à incrustação postmortem nos ramos dos corais. A segunda corresponde a uma associação simbiótica entre o serpulídeo $P$. sulcicarinatus e ambas as espécies de corais. Os tubos dos serpulídeos são registrados paralelos aos ramos do coral, atingindo a extremidade superior dos ramos e sendo encobertos por eles devido ao crescimento do coral. A relação simbiótica estudada entre serpulídeos e corais pode ser considerada como mutualismo, já que ambos são susceptíveis de se beneficiar um do outro. Este tipo de associação tem semelhanças com casos recentes de simbiose entre serpulídeos e corais, mas ainda não tinha sido encontrada no registro fóssil.

Palavras-chave: Serpulidae, Sabellidae, Scleractinia, simbiose, Hauteriviano, Argentina.

\section{INTRODUCTION}

The family Serpulidae, included in the Order Sabellida, comprises a group of sedentary polychaete annelids, which segregate a tube of calcium carbonate with a mucopolysaccharides matrix where they accommodate, that may be free or attached to some substrate. The tubes of the related family Sabellidae, also included in the Order Sabellida, are constructed with sediment particles agglutinated with mucus, with the exception of those of the genus Glomerula Brünnich Nielsen, which are calcareous. A few species of the family Cirratulidae also posses a calcareous tube (Vinn et al., 2008).

There are mentions of putative records of serpulid-like calcareous tubes that would make the history of this group go back into the Paleozoic, although most of these records have been reclassified as cirratulid polychaetes, vermetid gastropods, coralline algae or some problematic group (Ten Hove, 1994). First certain records of serpulids come from the Middle Triassic (Vinn \& Mutvei, 2009), and by the Middle Jurassic serpulid-like calcareous tubes exhibited a great degree of specialization and important taxonomic and ecological radiations, reaching the present times with a great diversity. The supra specific classification of fossil Serpulidae remains very disputed, in part because it is based, necessarily, in the morphology of their tubes; whilst that of the recent species is based on their soft tissues, and it is known that many present species segregate similar tubes (Ippolitov, 2007a; Ten Hove \& Kupriyanova, 2009). Additionally, being 
many of them attached to the substrate its irregularities influence the tube morphology. Most recent species have restricted distribution ranges, and species thought to be of worldwide distribution have been shown to be distinct species or complex of species, distinguishing between them by subtle morphological variations of their soft tissues (Ten Hove \& Kupriyanova, 2009). That is why the taxonomy of fossil serpulids is in fact parataxonomy of morphotypes, being difficult to make confident parallels with recent taxa. As a result of all these factors the group, in spite of having a rich fossil record along the Mesozoic and Cenozoic, has been of little interest to both taxonomists and biostratigraphers (Seilacher et al., 2008).

Goldfuss (1826-1833), in his monumental work "Petrefacta Germaniae", dealt with fossil serpulids, grouping them in three genera: Lumbricaria Münster, 1831, Serpula Linnaeus, 1758 and Terebella Linnaeus, 1767. Lumbricaria comprised six species, Terebella one, while Serpula included eighty, plus some subspecies. Later, such diversity was disaggregated into new genera, task in which the works of Parsch (1956), Regenhardt (1961), Ware (1975) and Jäger (1983, 2004) were important benchmarks. With few exceptions, all taxonomic works on this group were focused in European regions.

In Argentine bibliography there are a notorious lack of detailed studies about this taxonomic group, because most authors who recorded serpulids mentioned them only at family level; or following Goldfuss' criteria (1826-1833) indiscriminately cited them as "Serpula" indet. The main objective of this paper is to analyze post-mortem and symbiotic associations between sabellids, serpulids and scleractinian corals and to interpret its paleoecological significance. In particular, we describe one morphotype of sabellid and two morphotypes of serpulids found as encrusters on two species of scleractinian corals recorded from the Lower Cretaceous of the Neuquén Basin (west-central Argentina).

\section{MATERIAL AND METHODS}

The sabellid, serpulids and corals analysed in this work were collected in the Pilmatué Member of the Agrio Formation, mainly in Loma Rayoso locality (37³6'58.9" S, 7002'34.6" W), Neuquén Province, Argentina (Figure 1). They were collected from a lentiform coral-dominated shell bed of $4.60 \mathrm{~m}$ of maximum thickness and a lateral extension of $314 \mathrm{~m}$, composed mainly of reworked coral fragments. The coral bearing bed was dated by the presence of ammonoids belonging to the Olcostephanus (O.) laticosta Subzone of early Hauterivian age (see Aguirre-Urreta \& Rawson, 2001; Rodríguez, 2005). In the Agrio Formation corals are frequently recorded as reworked and parallel orientated fragments of $\mathrm{cm}$-sized ramose and globose colonies. We have identified at least three coral genera from the mentioned unit, namely Columastrea d'Orbigny, 1849, Placocoenia d'Orbigny, 1849 and Stereocaenia Alloiteau, 1952. These corals occur along with rich fossil assemblages of marine molluscs (see Lazo 2006, 2007).
A taphonomic analysis was performed on 150 randomly chosen fragments of coral branches collected in situ from the coral-dominated shell bed at Loma Rayoso. Main encrusting organisms on corals were cementing oysters (Amphidonte sp.), found in 126 samples (84\%); and secondarily serpulid-like tubes, found in 5 samples (3\%). No other encrusting macro-organisms, such as bryozoans or sponges, were found. Bivalve borings attributable to Gastrochaenolites isp. were found in 92 samples (61\%). Fragments of coral branches had a mean length of $4.4 \mathrm{~cm}$ but reaching a maximum length of $12.5 \mathrm{~cm}$, and a mean diameter of $2.2 \mathrm{~cm}$ with a maximum of $6.4 \mathrm{~cm}$.

We also examined 26 extra coral fragments bearing serpulid-like tubes collected loose but associated to the coral-dominated shell bed and eight coral fragments from the Lower Cretaceous of Neuquén deposited in the Paleontological Collection of the University of Buenos Aires (see below). In sum, 39 coral fragments carrying serpulid-like tubes were studied under naked eye and magnifying glass. Polished cross sections and thin sections of coral branches were made when necessary to improve descriptions.

We follow Jäger $(1983,2004)$ and WoRMS (World Register of Marine Species, 2011, online catalogue) for the classification of Polychaeta. For the description of the species we use the terminology defined in Regenhardt (1961), modified by Ware (1975) and Jäger (2004). For the classification of Scleractinia we follow Cairns et al. (2010).

Institutional abbreviation. CPBA, Colección de Paleontología, Facultad de Ciencias Exactas y Naturales, Universidad de Buenos Aires, Buenos Aires. Suffix number after CPBA means specimen number.

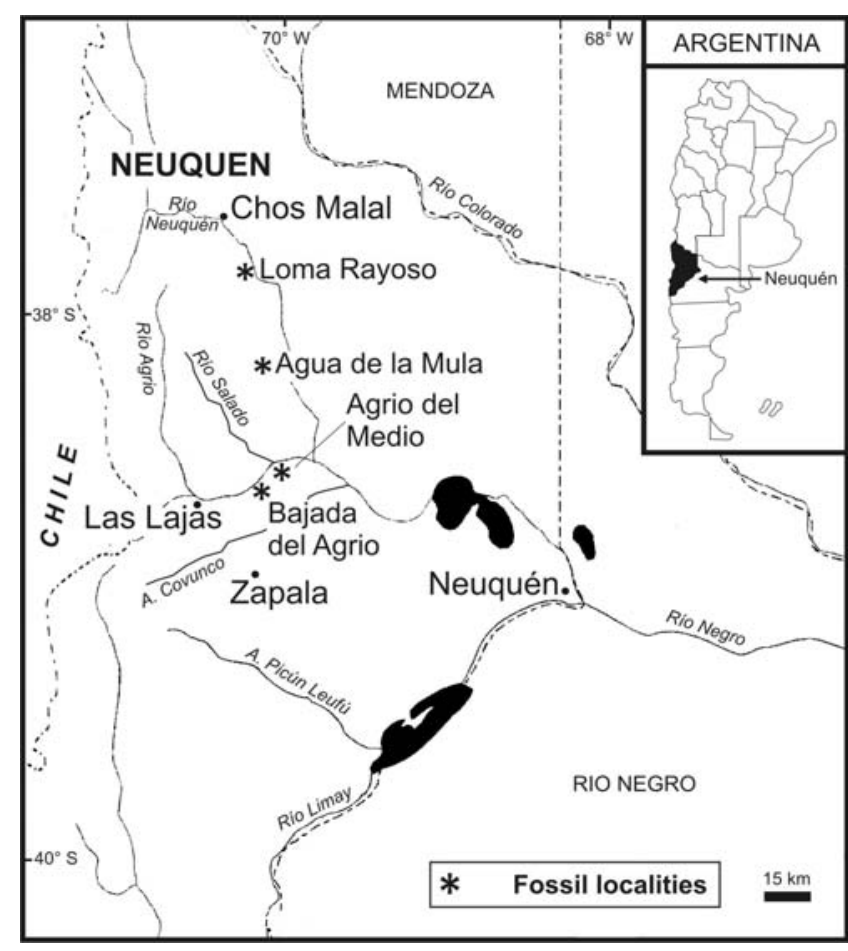

Figure 1. Map of fossil localities. 


\section{SYSTEMATIC PALEONTOLOGY}

\author{
Class ANTHOZOA Ehrenberg, 1834 \\ Order SCLERACTINIA Bourne, 1900 \\ Family THAMNASTERIIDAE Vaughan \& Wells, 1943 \\ Genus Stereocaenia Alloiteau, 1952
}

Type-species. Centrastraea collinaria d'Orbigny, 1850.

Stereocaenia triboleti (Koby, 1896)

(Figures 2A-L, 3A-D, F-I)

1896 Astrocoenia triboleti Koby, p 62, pl. 14, figs. 6-8. 1928 Astrocoenia cf. triboleti Koby. Gerth, p. 7.

1931 Astrocoenia cf. A. triboleti Koby. Weaver, p. 164.

1964 Stereoecania triboleti (Koby). Morycowa, pl. 23. (figs. 1, 2, $3 \mathrm{a}-\mathrm{b})$.

2000 Stereocaenia triboleti (Koby). Löser, p. 74.

2002 Stereocaenia triboleti (Koby). Löser et al., p. 617.

2011 Astrocoenia cf. A. triboleti Koby. Aguirre-Urreta et al., p. 478.

Materials. Thirty-three fragments of coral branches, 31 from Loma Rayoso (CPBA 19666, 19667, 19668), one from Agua de la Mula locality (CPBA 20539) and one from Bajada del Agrio locality (CPBA 19978).

Geographic occurrence. Bajada del Agrio, Agrio del Medio and Loma Rayoso localities, Neuquén Province, west-central Argentina (Figure 1).

Stratigraphic occurrence. Pilmatué Member of the Agrio Formation, Holcoptychites agrioensis, Olcostephanus (O.) laticosta and Hoplitocrioceras gentilii Subzones/Zones, early Hauterivian.

Description. Colonial, massive, thamnasterioid or cerioid. Colony ramose. Gemmation intracalicinal. Calices circular or polygonal with a diameter of $0.75-1 \mathrm{~mm}$. Septa compact, confluent, granulated marginally and laterally. Septa thickened by development of irregular multiple series of large trabeculae. First cycle of nine septa, sometimes eight or ten, reaching the styliform columella. Second cycle of the same number of septa, shorter. Synapticulae present. Endothecal dissepiments sparse. No wall between the corallites.

Family COLUMASTREIDAEAlloiteau, 1952 Genus Columastrea D’Orbigny, 1849

Type-species. Astrea striata Goldfuss, 1826.

Columastrea antiqua Gerth, 1928

(Figure 3E)

1928 Columnastrea antiqua Gerth, p. 5, tab. 1, figs. 4-4a. 1931 Columastraea antiqua Gerth. Weaver, p. 165, tab. 11, figs. 10-11.

1957 Columastraea antiqua Gerth. Von der Osten, p. 575, tab. 63, fig. 3 .

2000 Columastrea antiqua Gerth. Löser, p. 20.

2002 Columastrea antigua Gerth. Löser et al., p. 157.
2004 Columastrea antiqua Gerth. Lazo, p. 73, pl. 8.5, figs. 4-5. 2011 Columastrea antiqua Gerth. Aguirre-Urreta et al., p. 476,478 , figs. $8 \mathrm{~m}, 10 \mathrm{~h}$.

Materials. Six fragments of coral branches, one from Agua de la Mula locality (CPBA 19980) and 5 from Bajada del Agrio locality (CPBA 19978).

Geographic occurrence. Agua de la Mula and Bajada del Agrio localities, Neuquén Province, west-central Argentina (Figure 1).

Stratigraphic occurrence. Pilmatué Member of the Agrio Formation, Holcoptychites agrioensis and Olcostephanus (O.) laticosta Subzones, early Hauterivian.

Description. Colonial, massive, plocoid to subcerioid. Colony ramose. Gemmation extracalicinal. Perithecal dissepiments vesicular to subtabulate. Calices polygonal with a diameter of 1-2 mm. Costosepta compact, arranged radially, mostly non-confluent, but subconfluent in places. Septal margins finely granulated. First cycle of 12 septa reaching the styliform columella. Second cycle of 12 septa very short. Endothecal dissepiments thin, subtabulate.

\section{Class POLYCHAETA Grube, 1850 \\ Subclass CANALIPALPATA Rouse \& Fauchald, 1997 \\ Order SABELLIDA Fauchald, 1977 \\ Family SABELLIDAE Johnston, 1846 \\ Subfamily SABELLINAE Johnston, 1846 \\ Genus Glomerula Brünnich Nielsen, 1931}

Type-species. Serpulites gordialis von Schlotheim, 1820.

Diagnosis. Calcareous smooth tubes solitary or pseudocolonial, attached to some hard substrate in all their length, accumulating as they grow, forming loose loops and spirals, without basal edge, circular in cross-section, highly variable thickness of the tube wall with very small lumen in extreme cases, multiple layers in the tube wall with a crescent-shaped cavities between the layers. May reach a length of several tens of $\mathrm{cm}$, and show a slow but significant increase of size.

Synonyms. Calcisabella Perkins, 1991, p. 262. (Great Barrier Reef, Australia; Recent); Cycloserpula Parsch, 1956, p. 213 (Europe, India, North America, Tanzania, Tunisia; Bajocian/ Campanian) (Mehl \& Fürsich, 1997; Holzapfel, 1998; Aberhan, 2002; Ippolitov, 2007a); Omasaria Regenhardt, 1961, p. 45. (Argentina, Valanginian; India, middle Cretaceous; Germany, South of India, Late Cretaceous; France, late Maastrichtian) (Regenhardt, 1961; Chiplonkar \& Tapaswi, 1973; Chiplonkar \& Ghare, 1976).

Included species. Glomerula gordialis (von Schlotheim, 1820) (Europe, Israel, India; late Bathonian/Campanian); G. ilium (Goldfuss, 1831) (Europe, Oxfordian); G. lombricus (Defrance, 1827) (Europe, Argentina; Hauterivian/late Maastrichtian); G. nuntia Ziegler, 1984 (Bohemia, Late Cretaceous); G. piloseta (Perkins, 1991) (Great Barrier Reef, Australia; Recent); G. plexus (Sowerby, 1829) (England, Late Cretaceous); $G$. serpentina (Goldfuss, 1831) (France, Barremian); G. shankari 
Singh \& Dar Shukla, 1981 (Lesser Himalaya, Jurassic); G. vincetownensis Cook \& Ramsdell, 1991 (New Jersey, U.S.A.; Paleocene). (Chiplonkar \& Tapaswi, 1973; Hudson, 1958; Moosleitner, 2007).

Discussion. Regenhardt (1961) proposed the genus Omasaria for serpulid tubes encrusting other organisms, not forming compact and tight masses and not developing regular spirals as those of the genus Spiraserpula Regenhardt, 1961. The genus Omasaria was later considered junior synonym of Glomerula (Jäger, 1983, 2004).

Perkins (1991) discovered an extant sabellid with calcareous tube, Calcisabella piloseta Perkins, 1991, and because of their tube characteristics, including its ultrastructure, were almost indistinguishable with those of the genus Glomerula, both were synonymized and placed within the family Sabellidae. The ultrastructure of the tubes of Glomerula, being different from that of serpulids, allows to separate both families and suggests that the acquisition of calcareous tubes within Sabellidae in the early Mesozoic was an evolutionary convergence with serpulids (Vinn et al., 2008). Some recent cirratulid species (Polychaeta, Cirratulidae) also have a calcareous tube that is similar to that of Glomerula, but as both families are phylogenetically distant their similarities are regarded as another evolutionary convergence (Vinn et al., 2008).

Ippolitov (2007a), in spite of Jäger (2004), stated that Glomerula was unavailable, and placed the species included in this genus along with those of the genera Omasaria and Calcisabella in the genus Cycloserpula. Then, Ten Hove \& Kupriyanova (2009) gave reasons to affirm the validity of the genus Glomerula, though not being a serpulid but a sabellid. Radwanska (2004) correctly syonymized Glomerula and Omasaria; but incorrectly placed it within the family Serpulidae. Finally, Fauchald (2007) and the database of marine species WoRMS (2010) maintained the validity of the genus Omasaria in spite of Jäger (1983, 2004).

\section{Glomerula lombricus (Defrance, 1827)}

(Figures 2A-F, I)

1961 Glomerula scitula Regenhardt, p. 27, tab. 1, fig. 1. 1961 Glomerula saucia Regenhardt, p. 28, tab. 1, fig. 3. 1965 Glomerula saucia Regenhardt. Nestler, p. 74, tab. 4, fig. 11. 1973 Omasaria simplex Chiplonkar \& Tapaswi, p. 122, tab. 8, fig. 11. 1973 Omasaria variabilis Chiplonkar \& Tapaswi, p. 123, tab. 8, fig. 4. 1975 Glomerula saucia Regenhardt. Nestler, text-fig. 99.

Materials. Twelve fragments of branches of the coral species Stereocaenia triboleti with encrusting serpulids (CPBA 19666, 19667, 19668, 19978).

Geographic occurrence. Loma Rayoso and Bajada del Agrio localities, Neuquén province, west-central Argentina (Figure 1). Stratigraphic occurrence. Pilmatué Member of the Agrio Formation, Holcoptychites agrioensis and Olcostephanus (O.) laticosta Subzones, early Hauterivian.

Description. Calcareous tubes fixed to the substrate in all their length, of circular cross-section, diameter not exceeding 1 $\mathrm{mm}$, maximum diameter achieved at around $10 \mathrm{~mm}$ of length, then it remains relatively constant. Growth crawling and very winding, usually irregular, sometimes twisted over themselves. Surface ornamented with small wrinkles and bumps, but overall appearance is smooth. Tubes often in groups, that may cross or overgrow other tubes in small areas, but growth remains irregular and there is not parallel growth of the distinct tubes.

Discussion. Specimens found resemble those of the species Glomerula Brünnich Nielsen and Omasaria Regenhardt, synonymized by Jäger (1983, 2004). It has been found a close resemblance with "Serpula" funiculis Wolleman, 1899, erected for specimens from the Hauterivian of Harz Mountains of Germany and Jura Mountains of France, placed in the genus Omasaria by Regenhardt (1961), and later in the genus Glomerula by Jäger (2004). The Argentine species differs from it only in the diameter of the tube, that does not exceeds $1 \mathrm{~mm}$, while the European species reach a maximum diameter of 4 mm (Wolleman, 1902; Regenhardt, 1961).

Jäger (2004) stated that the relatively simple tubular morphology and the low variability of the genus Glomerula may hide different biological species. He found within it, varying statigraphically and geographically, a bimodal distribution of tubes diameter, which allowed him to differentiate two species: G. serpentina, with a normal (big) diameter and G. lombricus with a smaller diameter, less than 1 $\mathrm{mm}$. The studied specimens have a diameter of less than 1 $\mathrm{mm}$ and thus they are assigned to G. lombricus.

Glomerula gordialis, G. solitaria and G. plexus have a bigger diameter. The latter tend to form loosely packed bunches of tubes while G. ilium has cross sections with chaotic 3D ball-shaped coiling, features which have not been found in the studied specimens.

Family SERPULIDAE Rafinesque-Schmaltz, 1815

Subfamily SERPULINAE Rafinesque-Schmaltz, 1815 Genus Mucroserpula Regenhardt, 1961

Type-species. Mucroserpula mucroserpula Regenhardt, 1961.

Diagnosis. Solitary calcareous tubes, loop-like curved, of small to moderate size, widening at moderate rate and reaching a maximum diameter of $5 \mathrm{~mm}$. With triangular cross-section at early growth stages, rapidly giving way to pentagonal, subquadrangular or even ovoid cross-section. With a median longitudinal dorsal keel, forming a denticle at the aperture, and two supra lateral keels.

Included species. Mucroserpula arcuata (Münster, 1831) (Germany, Cenomanian); M. jaegeri Radwanska, 2004 (Poland, Late Oxfordian); M. mucroserpula Regenhardt, 1961 (Loma Rayoso, Neuquén, Argentina, early Hauterivian; Germany, Hauterivian/middle Cenomanian; England, Aptian; Czech Republic, Cenomanian/Santonian); M. mucroserpula cenomanica Lommerzheim, 1979 (Germany, Cenomanian); $M$. nitida Ware, 1975 (England, Aptian); M. quinquareata (Parsch, 1956) (Germany, ?Callovian); M. tricarinata (Sowerby, 1829) (Germany, England, Central Russia; Callovian/ Tithonian); M. velimia Ziegler, 1984 (Czech Republic, Cenomanian/Santonian); M. versabunda Regenhardt, 1961 
(Germany, Hauterivian); Mucroserpula sp. Hudson, 1958 (Israel, late Callovian); Mucroserpula sp. Moosleitner, 2007 (Drôme, France; late Barremian); Mucroserpula sp. Zitt et al., 2006 (Czech Republic, early Turonian). (Hudson, 1958; Negus \& Beauvais, 1979; Ziegler, 1984; Radwanska, 2004; Zitt et al., 2006; Ippolitov, 2007b; Moosleitner, 2007).

Discussion. The morphology of this genus is similar to that of genera Pomatoceros Philippi, 1844 and Propomatoceros Ware, 1975, and it is believed that diverged from the later by the Bathonian/Callovian (Ippolitov, 2007b). It differs from them by the presence of lateral keels, a minor diameter, the tube curvature and the loss of triangular cross-section in the early growth stage (Regenhardt, 1961; Ware, 1975). Jäger (2004) states that Mucroserpula common species from Upper Jurassic and Lower Cretaceous need a revision.

\section{Mucroserpula mucroserpula Regenhardt, 1961}

(Figures 2G-H)

1961 Mucroserpula mucroserpula Regenhardt, p. 47, tab. 4, fig. 2.

1975 Mucroserpula sp. cf. mucroserpula Regenhardt. Ware, p. 103, tab. 19, figs. $3,4,5$.

Materials. Two fragments of branches of the coral species Stereocaenia triboleti with encrusting serpulids (CPBA 19666).

Geographic occurrence. Loma Rayoso locality, Neuquén province, west-central Argentina (Figure 1).

Stratigraphic occurrence. Pilmatué Member of the Agrio Formation, Olcostephanus (O.) laticosta Subzone, early Hauterivian.

Description. Calcareous tubes with three longitudinal keels, one of them dorsal and two supra lateral. Tube cross-section initially sub-triangular, rapidly changing into a subquadrangular or ovoid shape, slightly higher than wide. The dorsal keel is irregular and undulate, and as the tube grows tends to be less prominent. The supra lateral keels are also somewhat irregular. Below them there are two longitudinal sutures, and the surface of the tubes bears transversal growth lines bent to the anterior portion in the dorsal section. The lumen is ovoid, with the maximum diameter vertically oriented. There are not lateral expansions where the tube contacts with the substrate, and the thickness of the walls remains uniform throughout the whole cross-section. The longest specimen, which retains the initial sector, shows three Ushaped successive bends (Figure 2G).

Discussion. Two specimens of this species have been found, one fragment of a tube of $5 \mathrm{~mm}$ in length and $3 \mathrm{~mm}$ in diameter (Figure $2 \mathrm{H}$ ), and a second one $30 \mathrm{~mm}$ long reaching a diameter of $2 \mathrm{~mm}$ (Figure $2 \mathrm{G}$ ). Both are encrusters on coral branches, attached to them in their whole preserved length. The specimens found are identical to Mucroserpula mucroserpula. Lommerzheim (1979) described the subspecies M. mucroserpula cenomanica, but a comparison with our specimens was impossible as we have not had access to the original material.

\author{
Genus Propomatoceros Ware, 1975
}

Type-species. Propomatoceros sulcicarinatus Ware, 1975.

Diagnosis. Tubes of medium or big size, with a diameter that may reach $10 \mathrm{~mm}$. Tubes are attached in all their length or rise over the substrate only in their terminal end. Tubes have triangular cross-section in early growth stage, then they become sub-triangular, sub-pentagonal or almost circular in later stages. Dorsal median keel well developed and thick. Longitudinal sutures in the middle of the lateral sides and in the median keel. Operculum not calcified. Lateral surfaces with thin growth lines reflected forward forming an arc from the base of the tube to the dorsal keel, with a tooth-like projection over the aperture.

Included species. Propomatoceros ares Ziegler, 1984 (Czech Republic, early Turonian); P. barskovi Ippolitov, 2007b (Central Russia, ?Poland; late Callovian); P. biplicatus (Reuss, 1845) (Germany, Turonian); P. canaliculatus (Münster, 1831) (Germany, Kimmeridgian/Tithonian); P. conformis (Goldfuss, 1831) (Germany, ?Bathonian/Kimmeridgian); P. davidsoni (Loriol, 1876) (Switzerland, Tithonian); P. dentata Ware, 1975 (England, early Aptian); P. gibbosus (Goldfuss, 1831) (Germany, Late Jurassic); P. gracilis Ware, 1975 (England, Aptian); P. keepingi Ware, 1975 (England, Aptian); P. limatus (Münster, 1831) (Europe, Late Jurassic); P. lophiodus (Goldfuss, 1831) (Europe, Cenomanian); P. lumbricalis (von Schlotheim, 1820) (Europe, Middle Jurassic); P. obtusus (Sowerby, 1829) (Europe, Santonian/Maastrichtian); $P$. pentagonus (Goldfuss, 1831) (Germany, ?Oxfordian); $P$. semicostatus (Regenhardt, 1961) (Germany, Barremian); $P$. slavicus Ziegler \& Michalik, 1980 (Carpathian Mountains, early Rhaetian); P. sublimax (Gerasimov, 1955) (Central Russia, middle Callovian); P. sulcatus (Sowerby, 1829) (England, Bajocian/Oxfordian); P. sulcicarinatus Ware, 1975 (Mendoza, Argentina, Valanginian; Loma Rayoso, Neuquén, Argentina, early Hauterivian; England, Aptian); P. torquatus (Quenstedt, 1858) (Germany, Middle Jurassic); P. trachinus (Goldfuss, 1831) (Germany, Cenomanian); P. triangularis (Goldfuss, 1831) (Europe, Santonian/Maastrichtian); P. triferulatus (Parsch, 1956) (Germany, early Kimmeridgian); P. trigona (Parsch, 1956) (Germany, Israel; late Callovian); Propomatoceros sp. Moosleitner, 2007 (Drôme, France; late Barremian). This list is not exhaustive, because about 20 nominal species with a questionable species status or uncertain generic affiliation may be added (Ippolitov, 2007b; Vinn \& Wilson, 2010).

Discussion. The genus Pomatoceros initially had a wide stratigraphic occurrence, ranging from Late Triassic to Holocene. Later, Ware (1975) included Late Triassic/Late Cretaceous forms in the new genus Propomatoceros. The main difference between Pomatoceros and Propomatoceros is that in the later the tubes tend to be sub-cylindrical and in some cases free at its end. They also differ in tube ornamentation. Pomatoceros is one of the few serpulids having a calcified operculum, whilst Propomatoceros has not. This characteristic is usually difficult to prove, but the earliest 
records of opercula of Pomatoceros-Spirobranchus type in the fossil record comes from Cenomanian deposits and from then become common (Lommerzheim, 1979). Opercula from Jurassic and Early Cretaceous Propomatoceros may have reached a diameter of $8-9 \mathrm{~mm}$ in the largest species, and it is unlikely that such remains, having existed, had not been discovered so far; so it follows that they appeared by that time (Ippolitov, 2007b). Jäger (2004) stated that genus Dorsoserpula Parsch, 1856 has served as collective name for serpulids with simple dorsal keel and triangular, and sometimes circular, cross-section; but has been redefined to include only those possessing two typical features: lateral tubes and tendency to be attached to cylindrical substrates, forming a spiral cage; and Propomatoceros has been used as provisional genus for those not having that characteristics. We have not found any lateral tube, and the tubes show, after initial stages, a tendency to a straight and vertically oriented growth, even when they are encrusting thin coral branches (Figure 3C); so we place them in Propomatoceros, but recognizing its provisional character as defined by Jäger (2004).

\section{Propomatoceros sulcicarinatus Ware, 1975}

(Figures 2I-L, 3)

1975 Propomatoceros sulcicarinata (sic) Ware, p. 99, tab. 18, figs. 1, 2, 3, 4.

2007b Propomatoceros sulcicarinatus Ware. Ippolitov, p. 432.

Materials. Thirty-seven fragments of branches of the coral species Stereocaenia triboleti and Columastrea antiqua with encrusting and-or bioimmured serpulids (CPBA 19666, 19667, 19668, 19978, 20539).

Geographic occurrence. Loma Rayoso, Bajada del Agrio and Agrio del Medio localities, Neuquén Province, west-central Argentina (Figure 1).

Stratigraphic occurrence. Pilmatué Member of the Agrio Formation, Holcoptychites agrioensis and Olcostephanus (O.) laticosta Subzones, Hoplitocrioceras Zone, early Hauterivian. Description. Calcareous tubes attached to the substrate, with sub-triangular cross-section and a dorsal keel. Lateral surfaces slightly convex, with fine transverse growth lines. Rapidly increasing diameter at first stages of growth, then stabilized, reaching a maximum diameter of $7 \mathrm{~mm}$. Sub-triangular crosssection gives way to a sub-circular one, and the tube may be meandering or slightly curled. Wall thickness may limit the lumen to half the diameter of the tube. Tubes have two well differentiated concentric layers, being the external one thicker, and in cross-section is noticed that the external layer shows an interruption where the tube contacts the substrate and a lateral thickening to the sides in the same portion of the tubes, increasing the contact with the substrate.

Discussion. Specimens here described resemble in all their characteristics those of the species Propomatoceros sulcicarinatus, erected for specimens from the Aptian of England. It was not possible to verify the presence of the denticle over the aperture, due to the state of wear of all the specimens. All specimens were found on coral branches, except one which was observed on the inner side of a valve of an oyster (Amphidonte sp.).

Similar specimens of Propomatoceros, probably belonging to $P$. sulcicarinatus, were recorded encrusting bivalve shells from the Valanginian Chachao Formation in Mendoza Province by S. Damborenea et al. (unpublished report of Yacimientos Petrolíferos Fiscales). Serpulids with a longitudinal dorsal keel, which probably belong to this species, was also cited by Lazo (2004) in the Pilmatué Member of the Agrio Formation, Neuquén Province.

Although Ware (1975) erected this species as $P$. sulcicarinata, the Latin feminine termination of the specific name contradicts that of the genus, which is masculine, so the correct specific name should be $P$. sulcicarinatus, as corrected by Ippolitov (2007b).

\section{SABELLID AND SERPULID-CORALASSOCIATIONS}

The studied sabellid and serpulid-coral associations are discussed in two separate sections, one dealing with postmortem encrustations and the other one dealing with symbiotic relationships.

\section{Post-mortem encrustation}

Regarding sabellids, the studied tubes of Glomerula have been found always on corals branches, but one sample (CPBA 19666-75) shows the tubes encrusting the inner side of the attached valve of the cementing oyster Amphidonte sp. (Figure $2 \mathrm{~F}$ ). Usually, there are not coral overgrowth on tubes of this species, but only in one sample (CPBA 19667-11) there is an incipient advance of the corallum over the tube that partially covers its surface (Figure 2B). In this case we infer that the sabellid settled on a dead portion of the coral, and the overgrowth was subsequently produced by the regeneration of the coral from a nearby living portion. Glomerula tubes do not show any preferential orientation or growing direction with respect to the coral branches and thus also points to a post-mortem encrustation. Regarding serpulids, the studied tubes of Mucroserpula do not show any sign of response of the coral to their attachment. Therefore encrustations of Glomerula and Mucroserpula are interpreted as post-mortem encrustations as no change has been noticed in the coral morphology.

All tubes of Propomatoceros from Loma Rayoso were found on coral branches, except one small specimen (CPBA 19666-65), which was observed on the inner side of the cementing oyster Amphidonte sp. which was in turn encrusting a coral branch (Figure 2L). In one sample (CPBA 19666-28), a coral fragment including the apical tip of the colony, there are two Propomatoceros tubes that overlay Glomerula tubes and grow close to the edge of the cementing oyster Amphidonte sp., which cover them partially. We infer that tubes settled almost simultaneously. Both tubes of Propomatoceros, after some initial curve, oriented their growth vertically upwards (Figure 2I) with respect to the coral branch. Besides this sample, there are Propomatoceros tubes encrusted on coral branches which do not show any 

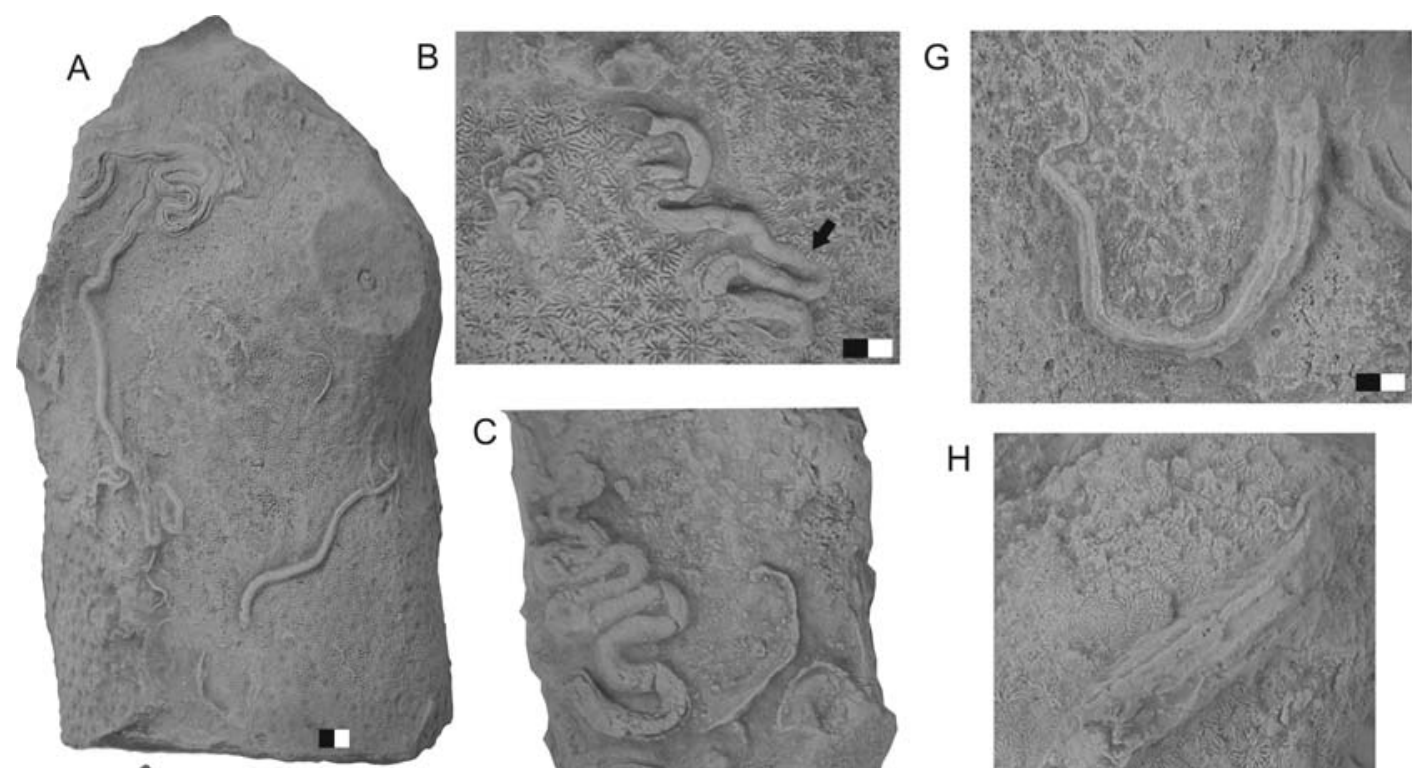

C
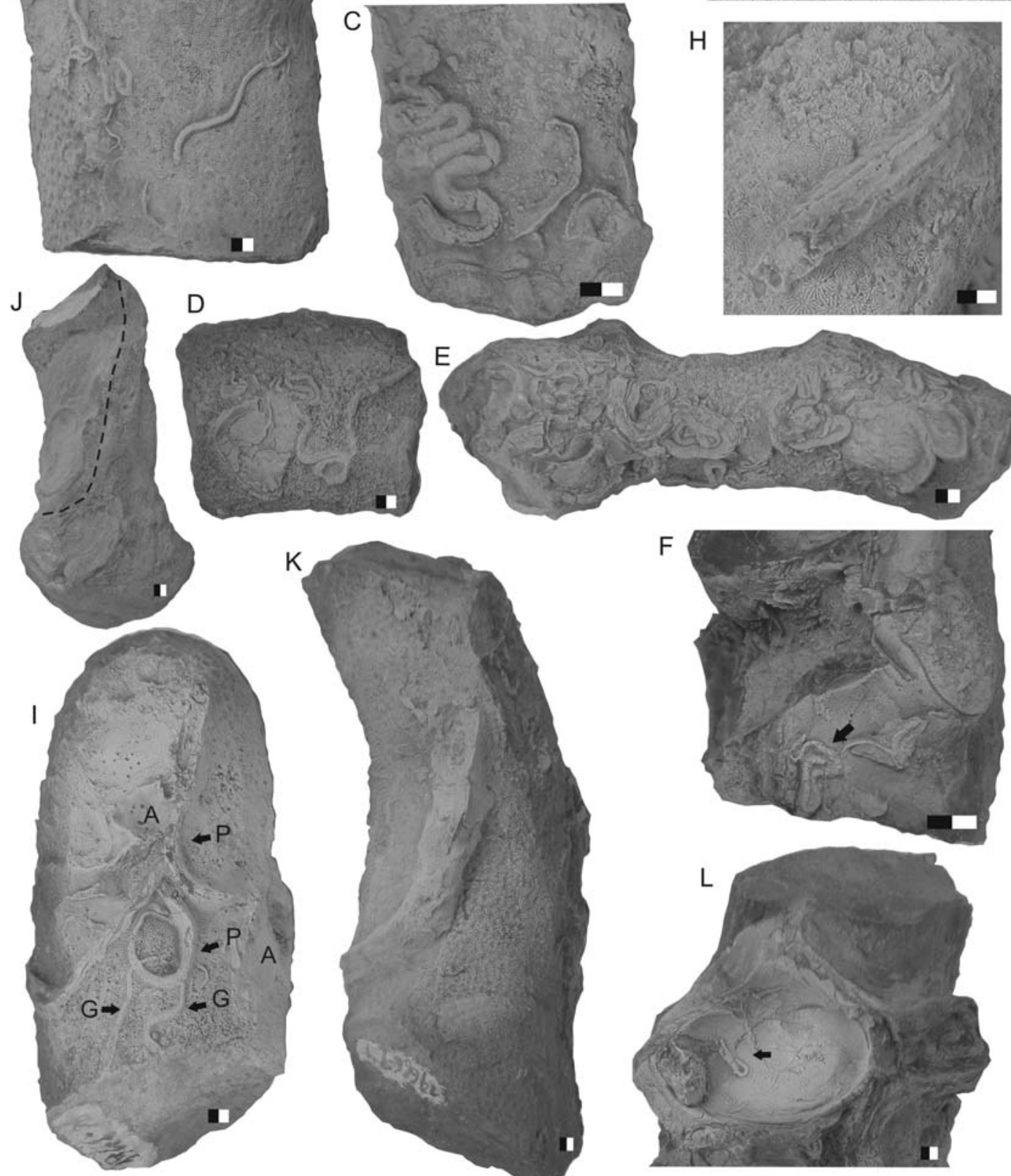
change of their morphology, but others show features that allow to infer a symbiotic relationship, that is discussed below.

\section{Symbiotic association}

In some samples (CPBA 19666-126; 19667-41) tubes of
Propomatoceros have been observed as external encrusters on coral branches but also as bioimmured tubes within the coral branches (Figure 3). The bioimmured tubes have a triangular or rounded cross-section and a similar diameter of the external encrusting tubes. Coral branches of the species
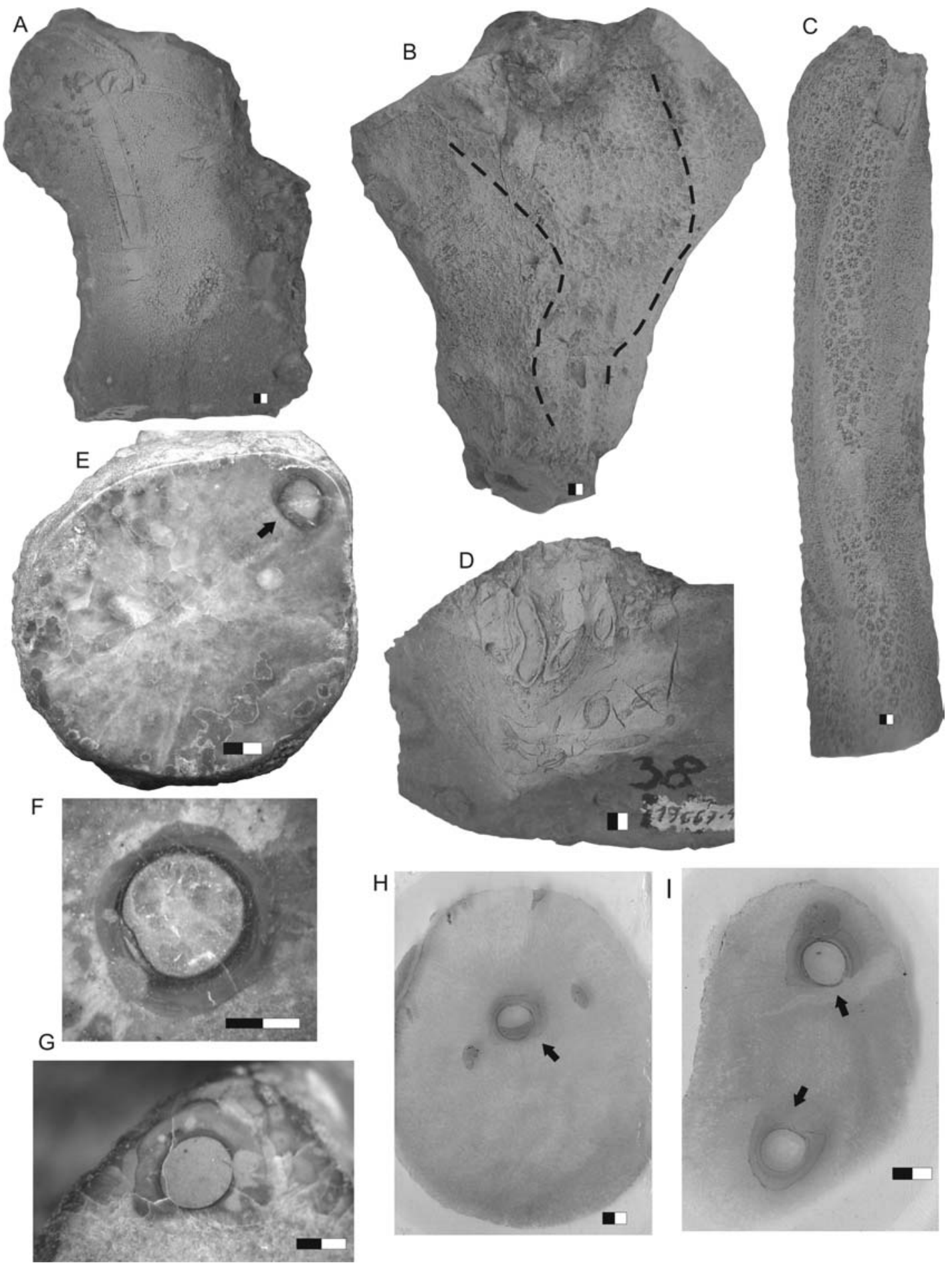

Figure 3. A-I, symbiotic serpulid-coral association: A, Propomatoceros sulcicarinatus tube bioimmured in a coral branch. CPBA 19666123; B, Propomatoceros sulcicarinatus, two tubes on a bifurcated coral, covered by corallum growing. CPBA 19666-58; C, Propomatoceros sulcicarinatus tube totally covered by corallum growing. CPBA 19666-91; D, bunch of Propomatoceros sulcicarinatus tubes on coral. CPBA 19667-41; E-G, polished transversal sections of coral fragments showing Propomatoceros sulcicarinatus tubes within coral branches, (E) CPBA 19978, (F) CPBA 19666-100, (G) CPBA 19666-78; H-I, thin sections of coral branches with Propomatoceros sulcicarinatus tubes, (H) CPBA 19666-130, (I) CPBA 19666-97. Figured corals belong to Stereocaenia triboleti except in E that belongs to Columastrea antiqua Gerth. Scale bars $=2 \mathrm{~mm}$. 
Columastrea antiqua with bioimmured tubes have a diameter of 1-2 cm (CPBA 19978-3, 21), but branches of Stereocaenia triboleti with Propomatoceros tubes bioimmured usually reach a diameter of $4 \mathrm{~cm}$ (e.g. CPBA 19666-1, 21, 38). Sections of coral branches show that most of the serpulids settled during early growth stages of the corals, when branches had a diameter less than $1 \mathrm{~cm}$, achieving later a diameter up to 4 $\mathrm{cm}$. Although in two samples (CPBA 19666-38, 120) the tubes are in branches with a diameter of $4-5 \mathrm{~cm}$ in areas near the surface of the branch indicating that the tubes settled during late growth stages of the coral branches. The tubes grew vertically upwards within the coral coping with the coral growth; their cross-section becoming nearly circular and with an even diameter. In one sample (CPBA 19666-97) there are up to four serpulids within the same coral branch, whose settlements occurred at different times during the coral growth.

\section{DISCUSSION}

\section{Recent cases of serpulid-coral symbiosis}

Recent symbiotic relationships between serpulids and scleractinian corals, where tubes are surrounded by coral tissues, were described in the genus Floriprotis Uchida, 1978, in some species of the genus Spirobranchus de Blainville, 1818 and in the genus Vermiliopsis Saint-Joseph, 1894.

The genus Floriprotis comprises only one species, $F$. sabiuraensis (Uchida, 1978), which is an obligate symbiont of scleractinian corals, with a distribution ranging from Japan to Indonesia and Fiji Islands in the Western Pacific. It segregates a tube with circular cross-section, and one of its unique characteristics is the absence of operculum, which is interpreted as an adaptation to this symbiosis (Ten Hove \& Kupriyanova, 2009).

The genus Spirobranchus comprises at least twenty species, many of them being complex group of related species (Ten Hove \& Kupriyanova, 2009). In this genus it has been reported cases of obligate symbiosis with corals in the species complex S. giganteus/corniculatus, and in the species $S$. gardineri Pixell, 1913, S. polycerus (Schmarda, 1861) and $S$. tetraceros (Schmarda, 1861) (Martín \& Britayev, 1998; Rowley, 2008). These species have a circumtropical distribution. Pillai (2009) described from Sorong (Indonesia) Spirobranchus sp. 5 , which is superficially similar to $S$. tetraceros, as growing on a branch of an unidentified coral and overlaid by it.

Although the phylogenetic relationships between the diverse genera within the family Serpulidae are not yet well defined, the genus Spirobranchus has obvious morphological similarities with the genus Pomatoceros and most likely they are synonyms. Pomatoceros has a rich fossil record and is regarded as having evolved from Propomatoceros (Ippolitov, 2007b; Ten Hove \& Kupriyanova, 2009; Ten Hove et al., 2011).

Neither Floriprotis nor Sprirobranchus seem to be selective with their hosts: Floriprotis has been recorded on five coral species of four distinct genera; $S$. gardineri on three species, $S$. polycerus and $S$. tetraceros on two species each one; and S. giganteus/corniculatus-complex on 19 species of 12 distinct genera of scleractinian corals (Martín \& Britayev, 1998). Rowley (2008) recorded, in S. giganteus Pallas, 1766, symbiosis with 40 species of 16 distinct colonial coral genera, most of them plocoid.

The case of Vermiliopsis is somewhat different. Larvae of an undescribed species of this genus settle on the Caribbean encrusting coral Stephanocoenia michelini MilneEdwards \& Haime, 1848, and their tubes are later surrounded by coral tissues, with their branchial crowns remaining regularly distributed on its surface (Martín \& Britayev, 1998). Taxonomic differences between the three genera, and differences between symbiosis of Vermiliopsis with that of the other two genera, suggest an independent origin of the symbiotic relationships.

Some associations between non-serpulid polychaetes and corals have also been cited. The eunicid (Polychaeta, Eunicidae) Lumbrineris flabellicola Fage, 1936 inhabits a self-secreted membranous tube attached to the exterior wall of solitary corals and causes a superficial to deep groove on the coral skeleton (Martinell \& Domènech, 2009). Similar grooves were found in the fossil record dating back to the Miocene.

Bergsma (2009) reported in Moorea, French Polynesia, one case of symbiosis between worms from the genus Spiochaetopterus Sars, 1853 (Polychaeta, Chaetopteridae) and corals of several genera, but being more common in those from the genus Montipora Blainville, 1830. These corals are colonial and platy, but the settling of the polychaetes on living corals induced in them the formation of long finger-like branches around the worm's tubes. The polychaete emerges from a hole on the tip of the structure, and as the coral has a high growth rate, the worm must continually extend its tube to avoid being overgrown. The tubes are produced also by crustaceans (Malacostraca, Amphipoda) and vermetids (Gastropoda, Vermetidae), and may reach a length of $122 \mathrm{~mm}$ in the case of the chaetopterids. This symbiosis, at least in the case of the amphipods, has been interpreted as a mutualism (Bergsma \& Martinez, 2011). A similar pattern, but with Polydora villosa Radashevsky \& Hsieh, 2000 (Polychaeta, Spionidae) on Montipora, was found in Taiwan (Liu \& Hsieh, 2000). Until now, with the exception of that cited by Martinell \& Domènech (2009), these types of structures have not been identified in the fossil record.

\section{Fossil cases of symbiosis between corals and serpulid or serpulid-like tubes}

Recent coral reefs harbour a great number of all types of symbionts, mutualists, commensalists or parasites, and serpulids occupy a prominent place among them; but surprisingly there are very few fossil records of macrosymbiosis between serpulid-like tubes and scleractinian corals. Inversely, many cases of endosymbiont worms have been described in the paleozoic Tabulata and colonial Rugosa corals, attributed to tentaculitoids (cornulitids and trypanoporids), polychaetes or incertae sedis organisms 
(Howell, 1962; Oliver, 1983; Tapanila, 2002; Zapalski, 2007; Vinn \& Mõtus, 2008; Mõtus \& Vinn, 2009). In some cases, as those of tentaculitoids, endosymbiosis has been explained as an adaptation to life on a growing host and an antipredatory strategy (Vinn, 2009, 2010).

Kolodziej (1995) cited in the Tithonian/early Berriasian of the Carpathian Mountains of Poland the presence of tubes, interpreted as belonging to serpulids, settled within the calices of Calamophylliopsis flabellum (Blainville, 1830), a colonial scleractinian coral with phaceloid calicular arrangement, growing both at the same time. The serpulid accessed to the gastric cavity of the polyps, but it was not possible to define precisely the nature of the symbiosis.

Within the calices of the colonial coral Tarbellastraea reussiana (Milne-Edwards \& Haime, 1950), from the Miocene of Poland, micro-tubes of the serpulid polychaete Josephella commensalis Baluk \& Radwanski, 1997 have been found. Polychaetes settled on live corals, which in some cases reacted depositing over them acicular sclerites, presumably aragonitic, and granular calcite (Baluk \& Radwanski, 1997). This genus comprises only one recent species, Josephella marenzelleri Caullery \& Mesnil, 1896, from which it has not been reported any case of commensalism with corals (Ten Hove \& Kupriyanova, 2009).

Sorauf \& Harries (2009) show a figure of a cut section of a rotatory colony of the coral Siderastrea radians (Pallas, 1766) from the Pleistocene of Florida, USA, with serpulid tubes overgrown by coral skeleton.

Structures similar to those produced by recent eunicid polychaetes in solitary corals have been reported in caryophylliid and flabellid solitary corals form the Pliocene of the Mediterranean Sea (Martinell \& Domènech, 2009), and the ichnogenus Sulcichnus Martinell \& Domènech has been proposed for them. This trace fossil seems to be present in many solitary corals from different geographical and stratigraphical provenance, but the producer has not been identified (Martinell \& Domènech, 2009 and references therein).

Voigt and Lafrenz (1973) described numerous vertical parallel tubes curled in a corkscrew shape, inserted in a coral colony from the Albian of England, which they attributed to a polychaete annelid ?"Serpula" gyrolithiformis Voigt \& Lafrenz, 1973.

On ammonites from the Early Jurassic of Germany serpulids of the species Serpula olifex Quenstedt have been observed settled on the flank of a juvenile ammonite shell, lengthening their tubes as the host's shell immured them as it grew. In this case, being the ammonite a nektonic organism, serpulids benefited with the movement of their host, but their lives ended at the same time, because serpulids couldn't survive ammonite death and posterior sinking of the shell (Seilacher et al., 2008). Andrew et al. (2011) reported undetermined serpulids attached on living ammonites from the Lower Jurassic of England, mostly Promicroceras Spath, 1925, in a relationship interpreted as parasitic, as they found a highly significant inverse correlation between the diameter of the ammonites at death and the ratio of attached serpulids.

\section{Comparison of the studied symbiotic association with recent and fossil examples}

In the cases of Floriprotis and Spirobranchus, it was postulated that serpulids settle on dead sectors of the corallum, which covers the tubes as it regenerates (Martín \& Britayev, 1998; ten Hove \& Kupriyanova, 2009). However, it was also stated that they settle on live coral tissue (Rowley, 2008), without explanations on how they evade the action of nematocysts. Spirobranchus giganteus has a selective distribution over certain corals, although it is not known if it corresponds to a preference for settlement or to differential survival according to coral species (Rowley, 2008). In the case described by Pillai (2009), serpulids settle on living corals and are overgrown by them.

In the studied case, evidence points to a preferential settling of the serpulids on small-sized live coral branches with a marked tendency to grow vertically upwards. The finding of serpulids on external surfaces of corals and within coral branches, and in one case on a bivalve shell, suggests that the symbiosis between them, unlike recent ones, was not obligatory but facultative.

In recent cases of symbiosis, serpulids may obtain protection against predators like fish and Crustacea (Rowley, 2008 and references therein) while being bioimmured by an organism having tentacles with nematocysts; but it is not clear whether the coral, in turn, gets some advantage from the association. It has been suggested that the polychaetes, by actively creating water currents for feeding, would improve water flow around coral surface, thus improving the elimination of waste products and/or availability of nutrients, and also would prevent algae settling and hinder predators access (Ben-Tzvi et al., 2006; Rowley, 2008).

It has been reported that in an almost dead colony of the coral species Cyphastrea chalcidicum (Forskål, 1775), areas surrounding tubes of $S$. giganteus recovered, while the rest of the colony died. Also in bleaching cases of colonies of the coral species Favia favus Forskål, 1775 and Favia laxa (Klunzinger, 1879), which also had S. giganteus tubes, areas surrounding the serpulid tubes remained unharmed. These cases give support to the assumption that the serpulids produce some benefit for the coral (Ben-Tzvi et al., 2006).

Recent cases of serpulid-coral associations, with one single exception (Pillai, 2009), engage platy corals. In the studied case, where the coral host had a ramose growing habit, may be added as an advantage for the polychaetes the possibility of growing vertically upwards from the sedimentwater interface and thus reaching a higher position into the water column, distant from bottom turbidity. Even though they may have settled on them just because of the scarcity of hard substrates, as it was interpreted for coral colonies growing on a soft substrate (see Lazo, 2007). The coral, in turn, may have obtained, by the serpulid settling, an increase of its diameter and the stiffness of its branches, especially in early stages of growth, taking into account that the environment where they lived has been interpreted as a shallow sea floor subject to frequent storms, where they were 
exposed to frequent breakage (Lazo, 2006) (Figure 4). Overall warm waters and oligotrophic conditions favoured the development of such coral colonies (Lazo, 2007). The coral probably also benefited by the presence of serpulids because the branchial crown of them was large enough to cover and protect the small corallites of $2 \mathrm{~mm}$ of maximum diameter in a way similar to an umbrella.

Accordingly to these facts the studied symbiosis could be characterized, from the ecological point of view, as a mutualism; because each component of the association would benefit from each other and from the structural point of view as an inter-growing or bioimmuration (Taylor, 1990; Darrell \& Taylor, 1993). The studied symbiosis between serpulids and corals from the Early Cretaceous of Argentina indicates that, in spite of the scarce records of such cases, both groups have established complex relationships by that time, and that the symbiosis of Propomatoceros, which appears to have been facultative, may give clues to understand the emergence in Spirobranchus, a related species, of an obligatory symbiosis.

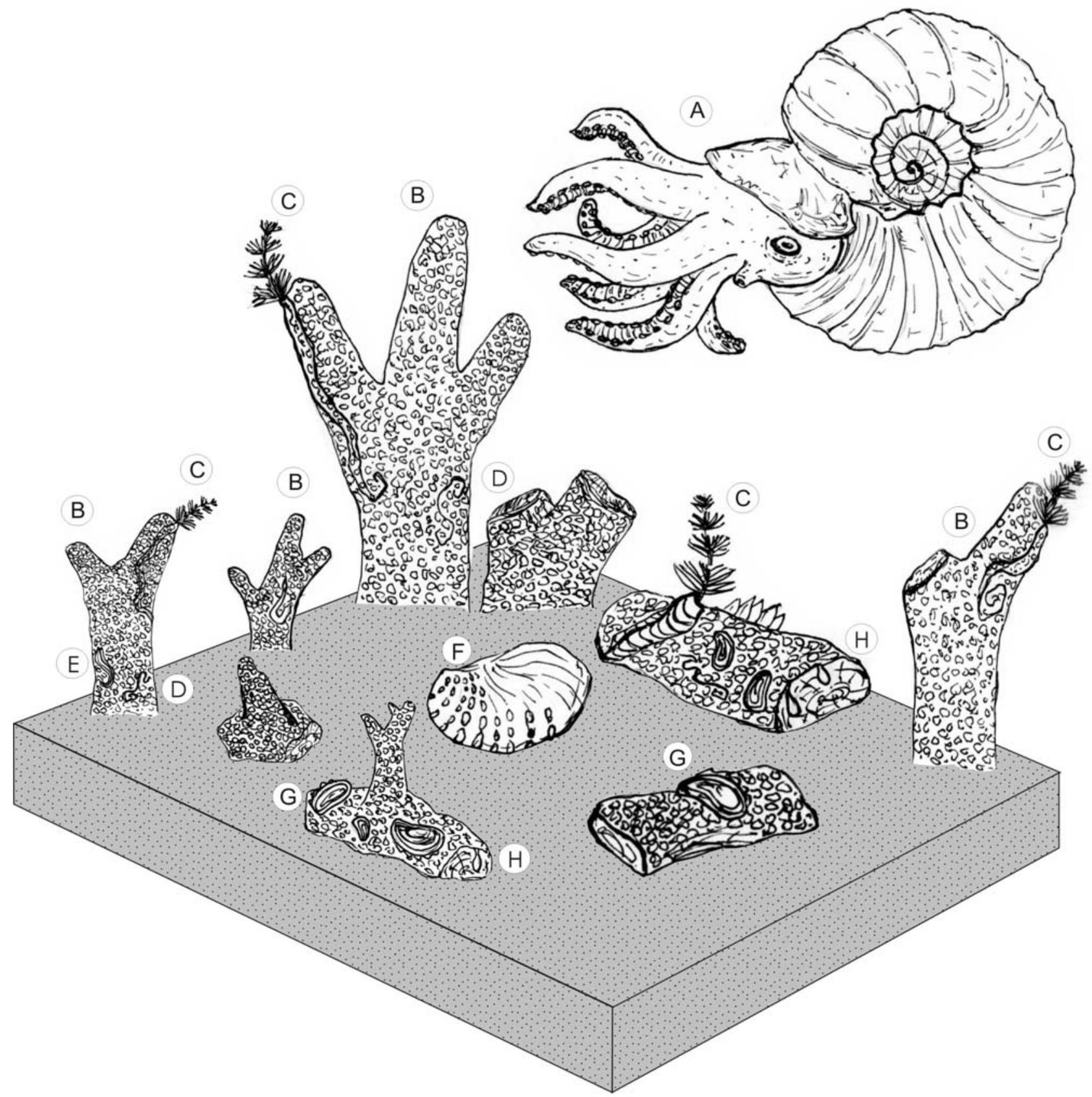

Figure 4. Reconstruction of the colonial corals with serpulids, oysters and boring organisms from Loma Rayoso, early Hauterivian, Agrio Formation, Neuquén Basin, Argentina. A, Olcostephanus (O.) laticosta. B, Stereocaenia triboleti/Columastrea antiqua. C, Propomatoceros sulcicarinatus. D, Glomerula lombricus. E, Mucroserpula mucroserpula. F, Trigoniid bivalve. G, Amphidonte sp. H, Gastrochaenolites isp. Note that Propomatoceros sulcicarinatus may encrust both living and dead coral branches. Not to scale. 


\section{CONCLUSIONS}

Encrustation patterns indicate that the studied Argentinean Hauterivian sabellids (Glomerula) and serpulids (Mucroserpula and Propomatoceros) settled on dead coral branches and use the corals as islands of hard substrate within an overall soft sea-floor.

A symbiotic association between Propomatoceros and coral colonies was identified based on bioimmuration of tubes within coral tissue and vertical orientation of tubes coping with coral growth and reaching the tips of coral branches. However, it is regarded as facultative because Propomatoceros tubes were recorded bioimmured by corals or just as external encrusters of presumably dead coral colonies.

The symbiotic association is interpreted as a mutualism. The serpulid received protection from the surrounding coral and may have reached a higher level into the water column as the coral grew upwards. In turn, the coral benefited because it obtained more rigid branches and protection against grazers, other encrusters and turbidity by the presence of large serpulid branchial crowns over the corallites. The crowns also provided water currents that improved feeding and waste dispersal.

The studied symbiosis between serpulids and corals indicates that both groups have established complex relationships by the late Mesozoic and the symbiosis of Propomatoceros may give clues to understand the emergence in Recent Spirobranchus, a related species, of an obligatory symbiosis.

\section{ACKNOWLEDGEMENTS}

The authors thank B. Kolodziej and H. Löser for providing bibliography; I. Stefanini for his invaluable assistance in field work and suggestions; F. Garberoglio for the reconstruction; and N. Burotto for translating from Latin Goldfuss's descriptions of species. B. Kolodziej and O. Vinn are acknowledged for their critical review of the manuscript, making it publishable. This is a contribution R-28 of the IDEAN. The authors thank especially the financing of the PICT 0464/2010 Bicentenario and UBACyT X001 projects in charge of M.B. Aguirre-Urreta (UBA).

\section{REFERENCES}

Aberhan, M.; Bussert, R.; Heinrich, W.-D.;Schrank, E.; Schultka, S.; Sames, B.; Kriwet, J. \& Kapilima, S. 2002. Palaeoecology and depositional environments of the Tendaguru Beds (Late Jurassic to Early Cretaceous, Tanzania). Fossil Redord, 5:1944. doi: 10.1002/mmng.20020050103

Aguirre-Urreta, M.B. \& Rawson, P.F. 2001. Lower Cretaceous ammonites from the Neuquén Basin, Argentina: a Hauterivian Olcostephanus fauna. Cretaceous Research, 22:763-778. doi:10.1006/cres.2001.0289

Aguirre-Urreta, M.B.; Lazo, D.G.; Griffin, M.; Vennari, V.; Parras, A.M.; Cataldo, C.; Garberoglio, R. \& Luci, L. 2011. Megainvertebrados del Cretácico y su importancia bioestratigráfica.
In: CONGRESO GEOLÓGICO ARGENTINO, 18, 2011. Relatorio, Neuquén, p. 465-488.

Alloiteau, J. 1952. Madreporaires post-paleozoiques. In: J. Piveteau (ed.) Traité de paléontologie, Masson et Cie., Tome I, p. 539684.

Andrew, C.; Howe, P.; Paul, C.R.C. \& Donovan, S.K. 2011. Epifaunal worm tubes on Lower Jurassic (Lower Lias) ammonites from Dorset. Proceedings of the Geologists' Association, 122:34-46. doi:10.1016/j.pgeola.2010.09.002

Baluk, W. \& Radwanski, A. 1997. The micropolychaete Josephella commensalis sp. $\mathrm{n}$. commensal of the scleractinian coral Tarbellastraea reussiana (Milne-Edwards \& Haime, 1850) from the Korytnica Clays (Middle Miocene; Holy Cross Mountains, Central Poland). Acta Geologica Polonica, 47:211-224.

Ben-Tzvi, O.; Einbinder, S. \& Brokovich, E. 2006. A beneficial association between a polychaete worm and a scleractinian coral? Coral Reefs, 25:98. doi: 10.1007/s00338-005-0084-3

Bergsma, G.S. 2009. Tube-dwelling coral symbionts induced significant morphological change in Montipora. Symbiosis, 49:143-150. doi: 10.1007/s13199-009-0047-5

Bergsma, G.S. \& Martinez, C.M. 2011. Mutually-induced morphological changes enhance growth and survival of corals. Marine Biology, 158:2267-2277. doi: 10.1007/s00227-0111731-6

Bourne, J.C. 1900. Anthozoa. In: E.R. Lankester (ed.) Treatise on Zoology, Adam and Charles Black, v. 2, p. 1-346.

Brünnich Nielsen, K.B. 1931. Serpulidae from the Senonian and Danian deposits of Denmark. Meddelelser fra Dansk Geologisk Forening, 8:71-113.

Cairns, S.D.; Baron-Szabo, R.; Budd, A.F.; Lathuilière, B.; Roniewicz, E.; Stolarski, J., \& Johnson, K.G. 2010. Corallosphere. Available at http://corallosphere.org; accessed on $02 / 05 / 2011$.

Chiplonkar, G.W. \& Tapaswi, P.M. 1973. Fossil Polychaetes from the Upper Cretaceous Rock Formations of South India. Part I. Proceedings of the Indian Academy of Science. Series B, Biological Science, 77:116-130. doi:10.1007/BF03045385

Chiplonkar, G.W. \& Ghare, M.A. 1976. Palaeontology of the Bagh Beds-Polychaeta. Chayanica Geologica, 2:37-57.

Cook, J.J. \& Ramsdell, R.C. 1991. Macrofossils from the Vincentown Formation (Paleocene) of New Jersey. Bulletin of the New Jersey Academy of Science 36:11-15.

Darrell, J.G. \& Taylor, P.D. 1993. Macrosymbiosis in corals: a review of fossil and potentially fossilizable examples. Courier Forschungsinstitut Senckenberg, 164:185-198.

Defrance, M. 1827. Serpule. In: F.G. Levrault (ed.) Dictionnaire des sciences naturelles, Le Normant, Tome 48, p. 549-572.

D’Orbigny, A. 1849. Notes sur des polypiers fossiles. V. Masson, París, 12 p.

Ehrenberg, C.G. 1834. Beiträge zur physiologischen Kenntnis der Corallenthiere im allgemeinen, und besonders des Rothen Meeres, nebst einem Versuche zur physiologischen Systematik derselben. Physikalische mathematische Abhandlungen der Königlichen Akademie der Wissenschaften zu Berlin, 1:225380.

Fauchald, K. 1977. The Polychaete worms. Definitions and keys to the orders, families and genera. Natural History Museum of Los Angeles County. Science Series, 28:1-188.

Fauchald, K. 2007. World Register of Polychaeta. Available at http:// www.marinespecies.org/aphia.php? $\mathrm{p}=$ sourcedetails\&id=47591; accessed on 16/03/2011.

Gerasimov, P.A. 1955. Index fossils of the Mesozoic of the central 
regions of the European part of the USSR. Part II. Echinoderms, Crustaceans, Worms, Bryozoans, and Corals of Jurassic Deposits. Moscow, Gosudarstvennogo Okeanograficheskogo Instituta, 90 p. [In Russian].

Gerth, H. 1928. Beiträge zur Kenntnis der Mesozoischen Koralenfaunen von Südamerika. Leidsche Geologische Mededeelingen, 3:1-16.

Goldfuss, A. 1826-1833. Petrefacta Germaniae. Düsseldorf, Arnz \& Comp., 252 p.

Grube, A.E. 1850. Die Familien der Anneliden. Archiv für Naturgeschichte, 16:249-364.

Holzapfel, S. 1998. Palökologie benthischer Faunengemeinschaften und Taxonomie der Bivalven im Jura von Südtunesien. Beringeria-Würzburger Geowissenschaftliche Mitteilungen, 22:1-199.

Howell, B.F. 1962. Worms. In: Moore, R.C. (ed.) Treatise of invertebrate paleontology, Part W, Miscelanea, Geological Society of America \& University of Kansas Press, p. 144-177.

Hudson, R.G.S. 1958. Actostroma gen. nov., a Jurassic stromatoporoid from Maktesh Hathira, Israel. Palaeontology, 1:87-98.

Ippolitov, A.P., 2007a. Contribution to the revision of some Late Callovian serpulids (Annelida, Polychaeta) of Central Russia: Part 1. Paleontological Journal, 41:260-267. doi:10.1134/ S0031030107030057

Ippolitov, A.P., 2007b. Contribution to the revision of some Late Callovian serpulids (Annelida, Polychaeta) of Central Russia: Part 2. Paleontological Journal, 41:75-81. doi: 10.1134/ S0031030107040090

Jäger, M. 1983. Serpulidae (Polychaeta sedentaria) aus der norddeutschen höheren Oberkreide-Systematik, Stratigraphie, Ökologie. Geologisches Jahrbuch A, 68:3-219.

Jäger, M. 2004. Serpulidae und Spirorbidae(Polychaeta sedentaria) aus Campan und Maastricht von Norddeutschland, den Niederlanden, Belgien und angrenzenden Gebieten. Geologisches Jahrbuch A, 157:121-249.

Johnston, G. 1845-1846. An index to the British annelids. Annals and Magazine of Natural History, 16:4-10.

Koby, F. 1895-1898. Monographie des Polypiers Crétacés de la Suisse. Mémoires de la Société Paléontologique Suisse, 22-24:1100.

Kolodziej, B. 1995. A symbiosis between the scleractinian coral Calamophylliopsis and a Polychaete (Tithonian-Berriasian). In: B. Lathuiliere \& J. Geister (eds.) Proceedings of the Second European regional meeting: coral reefs in the past, present and future, Publications du Service Geologique du Luxembourg, 29:121-122.

Lazo, D.G. 2004. Análisis de concentraciones fósiles del Cretácico Inferior de Cuenca Neuquina. Facultad de Ciencias Exactas y Naturales, Universidad de Buenos Aires, Tesis Doctoral, 337 p.

Lazo, D.G. 2006. Análisis tafonómico e inferencia del grado de mezcla temporal y espacial de la macrofauna del Miembro Pilmatué de la Formación Agrio, Cretácico Inferior de cuenca Neuquina, Argentina. Ameghiniana, 43:311-326.

Lazo, D.G. 2007. Análisis de biofacies y cambios realtivos del nivel del mar en el Miembro Pilmatué de la Formación Agrio, Cretácico Inferior de cuenca Neuquina. Ameghiniana, 44:73-89.

Liu, P.J. \& Hsieh, H.L. 2000. Burrow architecture of the spionid polychaete Polydora villosa in the corals Montipora and Porites. Zoological Studies, 39:47-54.

Lommerzheim, A. 1979. Monographische Bearbeitung der Serpulidae (Polychaeta Sedentaria) aus dem Cenoman
(Oberkreide) am Südwestrand des Münsterländer Beckens. Decheniana-Beihefte, 132:110-195.

Loriol, P. 1876. Monographie paléontologique des couches de la zone à Ammonites tenuilobatus (Badener Schichten) de Baden (Argovie). 1ère partie. Abhandlungen der Schweizerischen Paläontologischen Gesellschaft, 3:1-32.

Löser, H. 2000. Catalogue of Cretaceous corals. V.1. Repertoire of species. Dresden, CPress, 135 p.

Löser, H. \& 25 co-authors. 2002. Catalogue of Cretaceous corals. V. 2. List of citations. Dresden, CPress, $784 \mathrm{p}$.

Martín, D. \& Britayev, T.A. 1998. Symbiotic polychaetes: review of known species. Oceanography and Marine Biology: an Annual Review, 36:217-340.

Martinell, J. \& Domènech, R. 2009. Commensalism in the fossil record: Eunicid polychaete bioerosion on Pliocene solitary corals. Acta Palaeontologica Polonica, 54:143-154. doi:10.4202/ app.2009.0115

Mehl, D. \& Fürsich, F.T. 1997. Middle Jurassic Porifera from Kachchh, western India. Palaeontologische Zeitschrift, 71:1933. doi:10.1007/BF03022544

Moosleitner, G. 2007. Winzig, aber sensationell! Meine kleinste Fossilfundstelle. Fossilien, 5:288-298.

Morycowa, E. 1964. Hexacoralla des couches des Grodziszcze (Néocomien, Carpathes). Acta Palaeontologica Polonica, 9:1114.

Mõtus, M.-A. \& Vinn, O. 2009. The worms endosymbionts in tabulate corals from the Silurian of Podolia, Ukraine. Estonian Journal of Earth Sciences, 58:185-192. doi: 10.3176/ earth.2009.3.03

Münster, R.G. 1831. In: Goldfuss, A. (ed.) Petrefacta Germaniae, Arnz \& Co., 252 p.

Negus, P.E. \& Beauvais, L. 1979. The corals of Steeple Ashton, Wiltshire (English upper Oxfordian). Proceedings of the Geologists' Association, 90:213-227. doi:10.1016/S00167878(79)80007-3

Nestler, H. 1965. Die Rekonstruktion des Lebensraumes der Rügener Schreibkreide-Fauna (Unter-Maastricht) mit Hilfe der Paläoökologie und Paläobiologie. Beihefte zur Zeitschrift Geologie, 49:1-147.

Nestler, H. 1975. Die Fossilien der Rügener Schreibkreide. Die Neue Brehm-Bücherei, 486:1-120.

Oliver, W.A. 1983. Symbioses of Devonian rugose corals. Memoir of the Association of Australasian Palaeontologists, 1:261-274.

Osten, E. von der 1957. A fauna from the Lower Cretaceous Barranquín Formation of Venezuela. Journal of Paleontology, 31:63-65.

Parsch, K.O.A. 1956. Die Serpuliden-Fauna des südwest-deustchen Jura. Palaeontographica A, 107:211-240.

Perkins, T.H. 1991. Calcisabella piloseta, a new genus and species of Sabellinae (Polychaeta: Sabellidae). Bulletin of Marine Science, 48:261-267.

Pillai, T.G. 2009. Descriptions of new serpulid polychaetes from the Kimberleys of Australia and discussion of Australian and Indo-West Pacific species of Spirobranchus and superficially similar taxa. Records of the Australian Museum, 61:93-199. doi: 10.3853/j.0067-1975.61.2009.1489

Quenstedt, F.A. 1858. Atlas zum Jura. I-IV. Tubingen, Laupp und Siebeck, $842 \mathrm{p}$.

Radwanska, U. 2004. Tube-dwelling Polychaetes from the upper Oxfordian of Wapienno/Bielawy, Couiavia region, north-central Poland. Acta Geologica Polonica, 54:35-52.

Rafinesque-Schmaltz, C.S. 1815. Analyse de la Nature ou Tableau 
de l'Univers et des Corps Organisées. Palermo, Unknown editor, $224 \mathrm{p}$.

Regenhardt, H. 1961. Serpulidae (Polychaeta Sedentaria) aus der Kreide Mitteleuropas, ihre ökologische, taxionomische und stratigrafische Bewertung. Mitteilungen aus dem Geologischen Staatsinstitut in Hamburg, 30:5-115.

Reuss, A.E. 1845. Die Versteinerungen der böhmischen Kreideformation. Erste Abtheilung. Stuttgart, E. Schweizerbart'sche Verlagsbuchhandlung und Druckerei, $58 \mathrm{p}$.

Rodríguez, M.C. 2005. Geología y bioestratigrafía de las proximidades de Loma Rayoso, provincia de Neuquén. Facultad de Ciencias Exactas y Naturales, Universidad de Buenos Aires, Tesis de Licenciatura, 143 p.

Rouse, G.W. \& Fauchald, K. 1997. Cladistics and polychaetes. Zoologica Scripta, 26(2):139-204. doi:10.1111/j.14636409.1997.tb00412.x

Rowley, S. 2008. A critical evaluation of the symbiotic association between tropical tube-dwelling Polychaetes and their Hermatypic coral hosts, with a focus on Spirobranchus giganteus (Pallas, 1766). The Plymouth Student Scientist, 1:335353.

Schlotheim, E.F. von. 1820-23. Die Petrefactenkunde auf ihrem Jetzigen Standpunkte duch die Beschreibung seiner Sammlung Versteinerter und Fossiler Überreste des Thierund Pflanzenreichs der Vorwelt Erlautert. Gotha, Becker'schen Buchhandlung, lxii + 437 p., 52 pls. [Atlas pls. 15-29 [1820]; pls. 1-21 (1822); pls. 22-37 (1823).]

Seilacher, A.; Olivero, E.B.; Butts, S.H. \& Jäger, M. 2008. Softbottom tube worms: from irregular to programmed shell growth. Lethaia, 41:349-365. doi:10.1111/j.1502-3931.2008.00092.x

Singh, P. \& Dar Shukla, S. 1981. Fossils from the lower Tal: their age and its bearing on the stratigraphy of the lesser Himalaya. Geoscience Journal, 2:157-176.

Sorauf, J.E. \& Harries, P.J. 2009. Rotatory colonies of the corals Siderastrea radians and Solenastraea $\mathrm{sp.} \mathrm{(Cnidaria,} \mathrm{Scleractinia),}$ from the Pleistocene Bermont Formation, south Florida, USA. Palaeontology, 52:111-126. doi:10.1111/j.1475-4983.2008.00825.x

Sowerby, J.C. 1829. The mineral conchology of Great Britain. 6. Londres, Edition of the author, 230 p.

Tapanila, L. 2002. A new endosymbiont in Late Ordovician tabulate corals from Anticosti Island, eastern Canada. Ichnos, 9:1-40. doi:10.1080/10420940190034193

Taylor, P.D. 1990. Preservation of soft-bodied and other organisms by bioimmuration - A review. Palaeontology, 33(1):1-17.

Ten Hove, H.A. 1994. The dualistic relation between molluses and serpulid tube-worms. In: M. Coomans-Eustatia; R. Moolenbeek; W. Los \& P. Prins (eds.) De Horen en zijn echo. Verzameling essays opgedragen aan Dr. Henny Coomans ter gelegenheid van zjein afscheid van der Universiteir van Amsterdam op 9 September 1994: Amsterdam, Stichting Libri Antilliani, Zoölogisch Museum Amsterdam, p. 65-70.

Ten Hove, H.A. \& Kupriyanova, E.K. 2009. Taxonomy of Serpulidae (Annelida, Polychaeta): The state of affairs. Auckland, Magnolia Press, $126 \mathrm{p}$.

Ten Hove, H.A.; Fiege, D. \& Bellan, G. 2011. Pomatoceros Philippi, 1844. In: Read, G. \& Fauchald, K. (eds.) World Polychaeta database. Available at http://www.marinespecies.org/ aphia.php?p=taxdetails\&id=129572; accessed on 15/03/2011.
Vaughan, T.W. \& Wells, J.W. 1943. Revision of the suborders, families, and genera of Scleractinia. Geological Society of America Special Paper, 44:1-363.

Vinn, O. 2009. Attempted predation on Early Paleozoic cornulitids. Palaeogeography, Palaeoclimatology, Palaeoecology, 273:8791. doi:10.1016/j.palaeo.2008.12.004

Vinn, O. 2010. Adaptative strategies in the evolution of encrusting tentaculitoid tubeworms. Palaeogeography, Palaeoclimatology, Palaeoecology, 292:211-221. doi:10.1016/j.palaeo.2010.03.046

Vinn, O. \& Mõtus, M.-A. 2008. The earliest endosymbiotyc mineralized tubeworms from the Silurian of Podolia, Ukraine. Journal of Paleontology, 82:409-414. doi:10.1666/07-056.1

Vinn, O. \& Mutvei, H. 2009. Calcareous tubeworms of the Phanerozoic. Estonian Journal of Earth Sciences, 58:286-296. doi:10.3176/earth.2009.4.07

Vinn, O.; Ten Hove, H.A. \& Mutvei, H. 2008. On the tube ultrastructure and origin of calcification in sabellids (Annelida, Polychaeta). Palaeontology, 51:295-301. doi:10.1111/j.14754983.2008.00763.x

Vinn, O. \& Wilson, M.A. 2010. Sabellid-dominated shallow water calcareous polychaete tubeworm association from the equatorial Tethys Ocean (Matmor Formation, Middle Jurassic, Israel). Neues Jahrbuch fur Geologie und PaläontologieAbhandlungen, 258:31-38. doi:10.1127/0077-7749/2010/0080

Voigt, E. \& Lafrenz, H.R. 1973. Serpuliden (?) als Kommensalen in einer Stockkoralle aus dem englischen Ober-Albien. Neues Jahrbuch fur Geologie und Paläontogie-Abhandlungen Mh. H, 8:501-511.

Ware, S. 1975. British Lower Greensand Serpulidae. Palaeontology, 18:93-116.

Weaver, C. 1931. Paleontology of the Jurassic and Cretaceous of Western Central Argentina. Memoir University of Washington, 1:1-469.

Wolleman, A. 1902. Die Fauna der Lüneburger Kreide. Abhandlungen der Preussischen Geologischen Landesanstalt N.F, 37:1-129.

WoRMS. 2010. Omasaria Regenhardt, 1961. In: K. Fauchald (ed.), World Polychaeta database. Available at http:// www.marinespecies.org/aphia.php?p=taxdetails\&id=324518; accessed on 03/04/2011.

WoRMS. 2011. Serpulidae. In: G. Read \& K. Fauchald (eds.), World Polychaeta database. Available at http://www.marinespecies.org/ aphia.php?p=taxdetails\&id=988; accessed on 18/02/2011.

Zapalski, M.K. 2007. Parasitism versus commensalism: the case of Tabulate endobionts. Palaeontology, 50:1375-1380. doi:10.1111/j.1475-4983.2007.00716.x

Ziegler, V. 1984. Family Serpulidae (Polychaeta, Sedentaria) from the Bohemian Cretaceous Basin. Sbornik Národniho Muzea v Praze, Ser. B, 39:213-254.

Ziegler, V. \& Michalik, J. 1980. Late Triassic serpulids (Annelida, Polychaeta, Sedentaria) in the western Carpathians. Geologicky Sb. Bratislava, 31:627-640.

Zitt, J., Vodrázka; R., Hradecká, L.; Svobodová, M. \& Zágorsek, K. 2006. Late Cretaceous environments and communities as recorded at Chrtníky (Bohemian Cretaceous Basin, Czech Republic). Bulletin of Geosciences, 81:43-79.

Received in May, 2011; accepted in August, 2011 